\title{
Research on the Training Base Construction for Marketing Major in the View of Integration of Production and Education
}

\author{
Jiaxuan Wang, Longji Wei, Hairong Zeng \\ Qingdao Yellow Sea College, Qingdao, Shandong, 266427, China
}

Keywords: production and teaching integration, training base, marketing

\begin{abstract}
In order to cultivate innovative and applied talents in higher vocational colleges, it is necessary to pay attention to the construction of training bases. In this paper, from the perspective of the integration of production and teaching personnel training mode, combined with the principles of the construction of the campus marketing practice base and propose suggestion for the school training base construction model.
\end{abstract}

\section{Introduction}

To improve the quality of teaching and construction of vocational colleges cannot be separated from practice teaching and practice teaching cannot be separated from the integration of production and education training base construction. The practice base of integration of production and teaching is the hot point of practical teaching reform in higher vocational colleges, which is the key condition for training applied talents and serving the society. The marketing professional cultivation of applied talents has become an important content of practical teaching reform in economics and management colleges in China. Therefore, the major higher vocational schools in combination with the needs of market economic development, active marketing practice of professional teaching reform, innovation and market integration of production and education training base construction model.

\section{The meaning of the school training base within the integration of production and education}

Production and teaching integration of the school training base require the school personnel training in accordance with the needs of enterprises in accordance with the actual production and operation management requirements in the training base layout of the enterprise or store-style structure, allowing students to directly participate in the real business scene. Integration of production and teaching of the school training base is not only the premise of real business operations under the production base, but also practical teaching venue. To cultivate students' professional skills for the concept, combined with the actual needs of enterprises, both focus on improving the ability of students to innovate, but also focus on enterprise product development and market development, and truly integration of production and teaching.

The school training base construction principles of marketing professional integration of production and teaching

Marketing professional training base construction should reflect the advanced marketing concept. Need to use market research methods, constantly collecting domestic and international market developments and industry trends information, so that both for the integration of production and teaching training base within the school building and development direction, but also for students of applied ability Provide advanced learning platform. 
Production, practice teaching, scientific research is a combination of marketing professional college campus training base construction approach. Scientific principles require the training base of production, learning and research to promote and develop each other, which for the cultivation of applied talents, and comprehensively promote quality education, training base to maintain the scientific and rational play a key role, so as to strengthen the professional marketing Training base of the overall effectiveness.

Marketing professional training base in the school should rely on professional-industry, industry and education integration of the principles of building software, hardware facilities, and better practice teaching and social services. On-campus training base in the successful completion of the practice of teaching at the same time, to run professional, enterprise management mechanism to promote the sustainable development of training base within the school.

\section{The deficiencies of marketing professional training base school building model}

Most of the vocational colleges in the construction of marketing professional campus training base, from the marketing professional students should have the professional and technical ability to begin to develop students' practical ability and the construction of the campus training base also has a certain nature of training. However, the practice environment of these training bases is a kind of scenario simulation environment. In this kind of simulation scene, various marketing business can be carried out, which can improve students 'skill operation ability to a certain extent. But in training students' marketing practice application ability there are still some shortcomings.

In the practice teaching of marketing specialty, universities mostly introduce the simulation software into the campus training base, and the simulation software can introduce the marketing related business into the practical training base to carry out the practical teaching activities to a certain extent and experience certain business training. For example, many colleges and universities to introduce UFIDA sand table software for experiential teaching, training students' marketing practice ability, through sales, profits and other indicators reflect the student's training effect as soon as possible after graduation into professional roles have some help. However, the market environment facing enterprises is changing rapidly, business managers in order to adapt many changes in the environment, the need for continuous adjustment of business decisions.

Of course, to some extent, UF Sandbox software can reflect the real marketing business scenarios, but the pre-designed software program in advertising, product design and development, still cannot fully simulate the real career situation, the change is too simple, and real marketing business scenarios there are still some gaps.

Marketing training base of teaching software is mostly based on marketing business context design, is conducive to students familiar with the marketing business processes, improve the practical application ability. However, some software design companies pay too much attention to commercial, coupled with the design of non-professional, resulting in the software itself, there are certain flaws. For example, many colleges and universities generally use the entrepreneurial training software, is designed for students to innovate, entrepreneurial ability design, but some colleges and universities also apply it to the field of marketing practice teaching. Combined with the characteristics of marketing professionals, the software defects are as follows:

The software design of the product pricing does not really take into account the different regions of the consumer's income level and market conditions, the region where the price of each product is the same level. This approach is clearly inconsistent with the laws of the market, easy to mislead the beginner. The most reasonable pricing design should be in accordance with market rules for classification pricing design.

The software in the advertising investment and sales increase the relationship between the operational designs and there has been a drawback that the more advertising practitioners, the faster the sales increase. However, in actual operation, not the more the better advertising investment, because the advertising investment to combine the various stages of the product life cycle characteristics, market demand and other factors to a reasonable combination of inputs, received good results, sales have improve. 
In recent years, many colleges and universities in order to meet the educational authorities to carry out the assessment of education, training base to increase investment in the school, in a short period of time to complete the rapid completion of a number of school training base. This campus training base does not really combine the vocational education personnel training objectives and professional training characteristics cannot cultivate a truly realistic, high professional quality and professional ability of talent. For example, some colleges and universities that the campus training base as long as there are computers and related software, even if built, and only consider the cost of installing software, tend to be different levels, similar professional students at the same time. Follow-up software upgrades slow to keep up with the market and technology development speed, coupled with some late software upgrade cost is high, some colleges and universities simply give up the software upgrade, resulting in the training base into the school furnishings.

\section{The construction new model of marketing professional training base based on the integration of production and education}

Major colleges and universities should be based on professional characteristics and the school situation, in the construction of marketing professional campus training base at the same time, the establishment of some new models to make up for the school training base model deficiencies, such as construction - related business planning company, school branch, Physical stores and other new models. These new models can better close to the company's actual business, a more realistic reflection of the marketing professional environment, to further improve the practical application of students' ability

Major colleges and universities with marketing professional marketing system to set up planning companies to carry out the relevant marketing activities, so that students really participate in planning the company's management, experience the true role of marketing professional. Students can choose their own professional hobbies planning the company's marketing operations of the specific operation, by professional teachers and related business personnel to conduct daily business guidance. For example, in the holidays, the company anniversary activities during the organization of the relevant marketing projects related to the field of business investigation, and marketing related marketing projects to carry out various promotional activities and promotional activities. For students to participate in social practice and contact with the market to provide a real platform, and then fully enrich the student experience, improve the overall quality and practical application ability.

Major colleges and universities can cooperate with relevant enterprises to set up sales branches in the school, learn from the experience of school-enterprise cooperation model for the introduction of some consumer market groups for students in the school set up sales subsidiaries, such as FMCG, clothing companies, supermarkets and other daily necessities. The operation and management of the school sales branch can be jointly responsible by the enterprise and the marketing department, and recruiting marketing students to carry out the related marketing business, which can better combine the classroom teaching of the marketing major with the actual operation of the enterprise, For the students to provide a fitting business opportunities for the actual business, but also for graduate employment, teachers to participate in business practice provides a platform.

Entity store can be built by a marketing professional students operating independently, selffinancing business model. Its operation is guided by professional teachers, students to carry out market research, marketing and sales activities of the open model. Aimed at cultivating students practical hands-on ability and business innovation ability. Fully mobilize the enthusiasm of the students, the knowledge learned to better apply to practice, and in practice, the accumulation of work experience.

As the focus of vocational education reform, it is necessary to set up practical training base in the teaching of marketing specialty, and to establish the training base in line with the demand of training qualified personnel. The construction of the campus marketing training base not only helps the students to deepen the understanding of the theoretical knowledge, master the professional skills and skills, but also can stimulate students' interest in theoretical knowledge, deepen the understanding and application of the theoretical knowledge, Analyze problems and solve problems. 


\section{Acknowledgements}

Relying on profession to develop industry, integration of production and teaching development research and practice (pilot) (2015jyy01)

\section{References}

[1] Dong Yuan. Progress the practice of teaching reform, build a practice-based engineering education system. Chinese Higher Education, 55(12), pp.68-70, 2011

[2] Ye Zhipeng, Jin Pei-hua.Study on the Practical Teaching of Engineering Education in China, Higher Education of Engineering Research, 8 (5), pp.87- 91, 2013

[3]Frey, K. Die Projektmethode. Beltz -Verlag. Weinheim, Basel, 2002.

[4] Zeng Qingchun. Exploration and practice of the construction of the campus marketing training base. Educational Administration, 12(10), pp. 18- 20, 2012

[5] Zhu Jinfu. Marketing professional training base construction of the campus Vocational Education Forum, 9(6), pp.58- 61, 2011

[6] Zhai Yan, Wan Liangjie. Practice training company marketing professional on-campus training model. Journal of Xiangfan University, 8(4), pp.85-87, 2014 